\title{
Some Perspectives on the Problems and Prospects of Women Education, Empowerment and Gender Role in Nigeria
}

\author{
Ma'aruf Tijjani \\ Amina Musa Tahir \\ Department of Educational Foundations, Sa'adatu Rimi College of Education, \\ P M B 3218, Kumbotso Zaria Road,Kano,Nigeria
}

\section{Doi:10.5901/mjss.2014.v5n26p66}

\section{Abstract}

This paper highlights the need for psychological, physiological and dispositional compatibility of Women and the ability to enhance their human resourcefulness and empowerment through the acquisition and use of the 'right' type of education. The process of the acquisition and use of education, it is believed, can only come about through an understanding of the causal and physiological linkages between the nature and application of education, empowerment and the various roles expected from each gender. Just knowing the education-empowerment -gender role relationships might not be enough without knowing more and appraising the relationship that ought to work among these three concepts. This paper focuses on the ongoing concerns about education in Nigeria with regards to it's links with the acquisition by Women as well as their empowerment and gender roles. It further examines the rather artificial euphoric concerning the participation of Women in specific and more patriarchal professions and therefore creating a vacuum in feminine and important social roles. Finally, some recommendations were given on realignment of women education to enhance their natural roles using education as a tool.

Keywords: Women, Education, Empowerment, Gender Role.

\section{Introduction}

The issue of female subordination is as old as human history and cuts across various societies, cultures, civilizations and ideologies. The problem has a global perspective and is not particularly associated with a certain regional grouping geopolitical entity or ideological orientation. Glaringly, it also transcends all epochs and even with the scientific and technological advancements, female subordination is still a thorny issue. Women emancipation in realistic and positive sense is still a mirage even in the western Euro-America world.

It goes without saying that education helps men and Women claim their 'rights' and realize their potentials in economic, political and social spheres of life. It is also a powerful way, through which people lift up their natural and physiological role-playing positions of life. This goes with Dauda's (2010:3) assertion that Education is a fundamental instrument which differentiates a fully developed human being from other mammals and is a criterion for measuring the mental, spiritual, po1itical and to some extent, the economic development of man.Education is therefore a necessary ingredient for a meaningful development of all human beings as well as their society.

Similarly, Aja-Okorie (2013:273) in specific terms, views education as a means that helps Women take advantage of opportunities that could benefit them and their families and preparing them for the labor force... She further asserts that Women's education leads 'directly' to 'better' economic growth for the society.

To demonstrate further concerns for Women, Olawepo \&Jekayinfa (1999:2) highlights that The Beijing Conference (1995) on Women has inter alia recommended the implementation of an affirmative action on; a) giving Women. $30 \%$ of the appointive positions of leadership at ward, state and national levels, b) ensuring that the concerns of Women, like those of, men to occupy the center stage of all issues (democratic change; c) 30\% representation of Women in appointive positions and d) ensuring that $10 \%$ of the annual budget should be devoted to programmes on empowerment.

All these go a long way to show the multi faceted need for education by all and more direly for Women. In other words, for the life of mankind to be meaningful, purposeful, goal-oriented, successful, happy and prosperous, as well as live in peace and tranquility and achieve societal concord, men and Women must acquire a qualitative, functional, roleoriented, useful, positively beneficial and goal oriented education. Dauda (2010:3) concludes that there is no denying the fact that for both men and Women to enjoy a truly successful life, they must acquire some qualitative, role oriented and positively utilitarian Education. Education in other words, is the basis for the socio-political, economic, physical, moral, spiritual, scientific and technological development of both the individual and the society within which they live.

Despite these lofty assertions and conclusions about the indispensability, measurements and goal-settings about Women education, much need to be considered about what type of education and what job best fit a woman considering 
her gullibility, physiological and psychological characteristics. It needs not to be misconstrued that the pressure and demand for certain category of jobs are both de-womanising and dehumanizing for the Womenfolk though some of the Women are working with the deceitful belief that they can do "whatever" men do. The Women in particular, as the life vein of the society, and the custodians of its distinct socio-cultural values, and as the first teachers of all Sons and daughters born in the society, ought to be given Education which is both biologically and culturally suitable and relevant to their distinct societal roles and their natural disposition.

\section{Women Education: An Overview}

Having noted that Education is a fundamental instrument for individual and societal development, it suggests that for the individual to develop mentally, psychologically, morally, socially, politically, and physically, he needs a sound education which is not necessarily quantitative but qualitative and compatible with his disposition. Equally, it is also of vital importance that the two sexes should have access to education up to the highest level possible. However, the Creator of mankind has through His wisdom created the male and female to be both physiologically and psychologically different. Such differences are manifested in their natural physique, stamina, temperament and psychological disposition. These innate natural differences ought to inform a nation of the type of education its citizens should acquire which will finally determine the type of professional or academic discipline they are to pursue in their future endeavors (sex-wise). Thus, any unguided educational training which makes either of the two sexes to pursue a line or discipline which is not in consonance with the natural disposition of the student usually ends up in total confusion, resulting in educational, moral and professional mismatch.

Dauda (2010:15) cautions that it could be inferred that there is a sinister motive behind the aggressive brainwashing to 'enlighten' Women through 'education' to be 'socially, economically and politically empowered' just as the empowerment campaign might tantamount to bringing the Women out of their matrimonial homes, exploit them, over use them, de-womanize them, break their homes and land them in a perpetual state of distress as mistresses devoid of societal honour and respect.

Undoubtedly, many communities and societies are in a very serious dilemma regarding the issue of Women's education. And this is because of the existence of paradoxical situations. That is, on the one hand, there is the obvious and invariable need of educating the Women in order to facilitate their smooth and whole-some development physically, mentally, socially morally and to make them appreciate their vital role in the preservation life and the perpetuation of the distinct cultural norms as well as the moral values of the society. And on other hand, western education-as it is being transmitted- is associated with some disturbing negative developments such as anti-family propaganda campaigns and the popularization of lesbianism, particularly through western Euro-American sponsored Women liberation movement.

Women education and empowerment has received a considerable attention worldwide as the following tabular and graphical presentation shows the case of the United States of America (1985-2012) Labour force distribution. Unfortunately, despite these occupational distributions women appear to be more or less at a receiving end as far as empowerment is concerned in most 'developing' countries including Nigeria and when empowered, certain jobs taken by them derails them from discharging their fundamental family roles.

Women as a percentage of the total employed in selected occupations, 1985-2012 annual averages

\begin{tabular}{|l|c|c|c|}
\hline \multirow{2}{*}{ Occupation } & \multicolumn{3}{|c|}{ Percentage of Total Employed } \\
\cline { 2 - 4 } & $\mathbf{1 9 8 5}$ & $\mathbf{2 0 0 0}$ & $\mathbf{2 0 1 2}$ \\
\hline Social Workers & & 74 & 80.6 \\
\hline Medical and Health Managers & 59.2 & 78.4 & 69.7 \\
\hline Accountants and Auditors & 44.1 & 59.4 & 60.9 \\
\hline Pharmacists & 29.8 & 51.7 & 53.7 \\
\hline Financial Managers & 35.7 & 50.5 & 53.5 \\
\hline Purchasing Managers & 24.4 & 43.3 & 50.9 \\
\hline Teachers (College and University) & 35.2 & 42.7 & 48.2 \\
\hline Chemists (except Biochemists) & 21 & 29.8 & 44.2 \\
\hline Lawyers & 18.1 & 29.2 & 50.4 \\
\hline Dentists & & 19.4 & 24.2 \\
\hline Architects & & 20.1 & 23.5 \\
\hline Industrial Engineers & & 17.2 & 18.8 \\
\hline Economists & & 55 & \\
\hline
\end{tabular}

Source: Bureau of Labor Statistics (BLS), Current Population Survey (CPS)/Graph by the Women's Bureau, U.S. Department of Labor. 


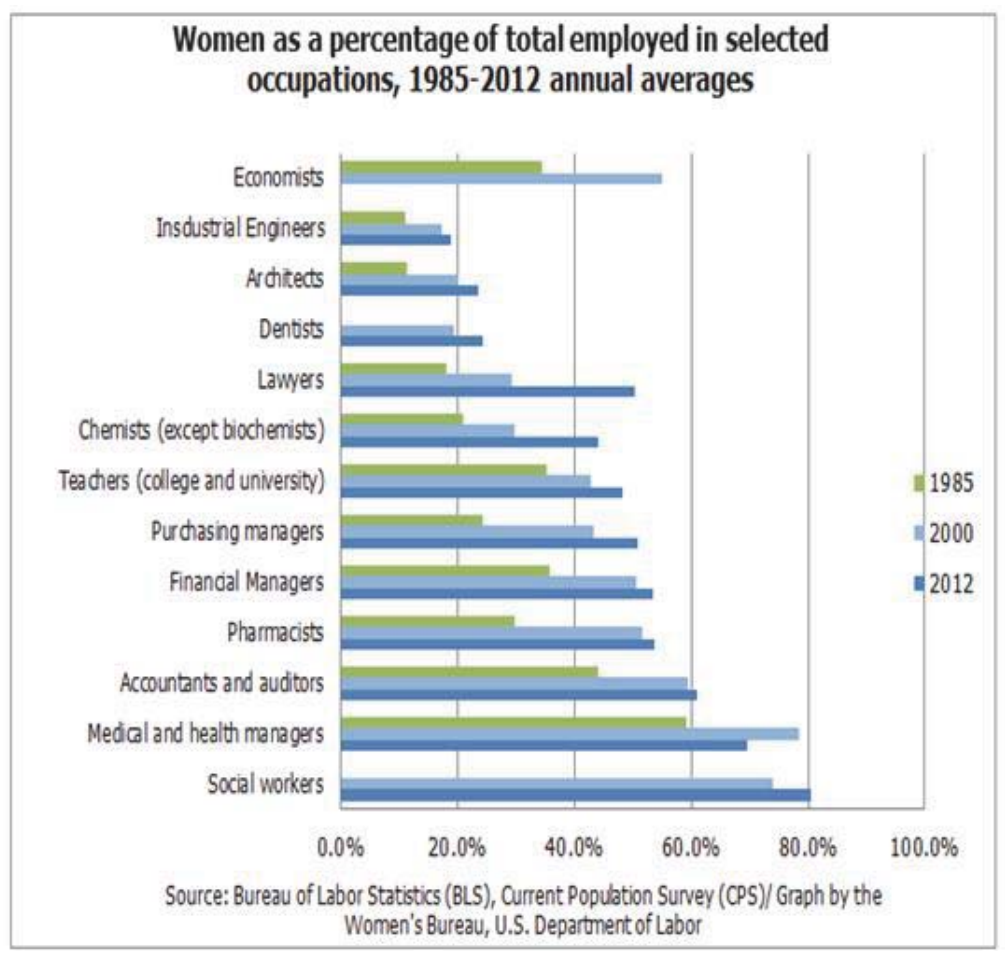

\section{Women's Dual Role}

Prospects (1999:148) a United Nations Educational and Cultural Organisation (UNESCO) Publication on interdisciplinary and development issues in education brought to limelight some of the key issues as far as Women education and their family roles are concerned. It further asserts that traditionally, Women have the major responsibility for the care of children and in close association with this they have in most countries also the duty of attending to the domestic needs of the family. "In societies where Women's other employment is informal, for example, in farming communities where caring for livestock, seasonal involvement in harvesting, some marketing, can be simply integrated into a woman's everyday activities, the dual role has not been perceived as such; Women have simply combined domesticity and the care and supervision of young children with these other tasks....

However, in industrialized societies the involvement of Women as paid employees in work outside the home has made divided responsibilities more obvious: established hours of paid work and the location of workplace usually differentiate Women's two spheres of endeavours-home and workplace. The resulting effects are that in many societies Women have taken on full-time work outside the home with no reduction in their domestic chores. Some contemporary societies anxious to include Women in the workforce have tried to reduce their domestic load by creating crèches, kindergartens, child-care facilities. Even so, Women have continued to have the tasks of shopping, taking children to and from kindergarten, housework, preparing the evening meal, looking after the well-being of the family - responsibilities meagrely recognized in the consideration of the niggardly natural disposition of Women. 


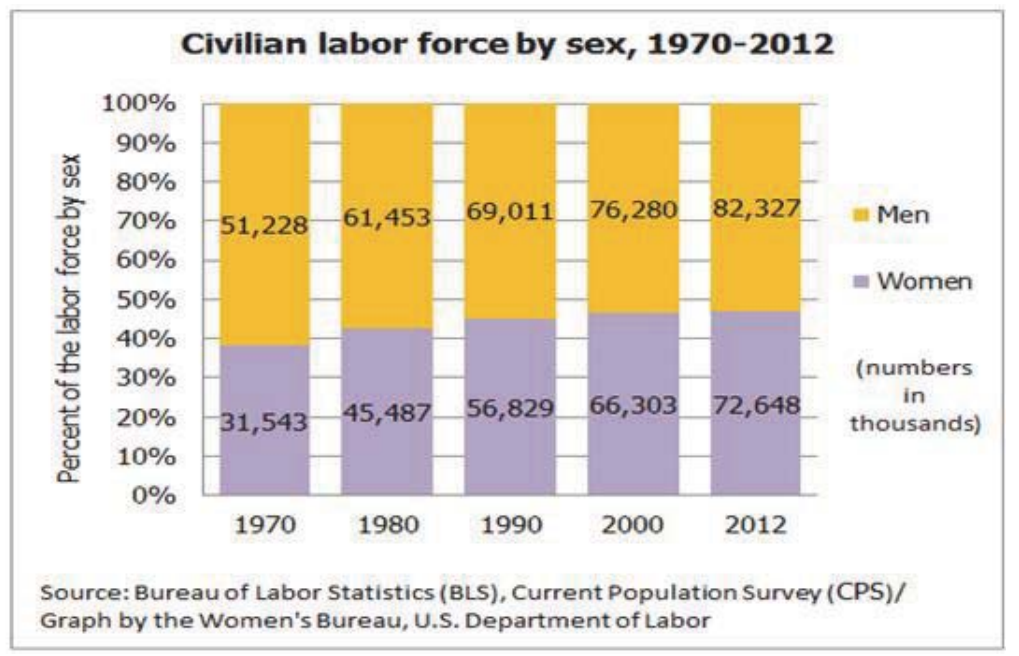

Jowell et al. (1988) as cited in Prospects (1990) holds that Women's dual role affects their education and employment prospects by reducing the time and energy available for higher studies or a professional career and this could lead to differences in social class as Women; though Women belonging to an affluent social class may be able to employ domestic help for housework and child-care. Among less affluent social classes however, in countries where cheap domestic help is hard to find, in countries where public provision of child-care facilities is poor,

Women very often have to cope with excessive demands.

\section{Women Education and Gender Role}

Women Education is undoubtedly a must; But the one million dollar questions are: Which type of education will be considered a must for them to acquire and which type of career or empowerment can be considered suitable for them -as mothers of all- and the overall positive growth and development of a society?. Can the education be acquired and job is secured at all costs, and for the mere sake of paper qualification objective? And for how long Can the Women continue to tolerate being sexually exploited or harassed or aggressively dc-womanized in the process of schooling and working in the office?

Further questionably significant issues are; can Women education be acquired without jeopardizing the fundamental role of the Women in the perpetual growth and smooth development, as well as the positive progress of the nation? In other words, can Women's education go side-by-side with a successful family life and the up-bringing of psychologically, socially and morally healthy children?

For obvious reasons, there is the dire need to counsel the Women to take up professions and office works which are in conformity with their natural disposition. Life between male and female members of the society should have to be based on the principle of complimenting each other's efforts, rather than be based on cut-throat competition, mutual antagonism and sexual anarchy.

The education of Women which is undoubtedly role-oriented and is geared towards both personal and societal development in a positive sense, is that type of education which equips the Women with all the necessary tools needed for the effective discharge of their own peculiar roles in the service of the nation. Depriving children of parental care and particularly motherly affection, love and training, will invariably produce socially and psychologically imbalanced children who will grow up to be angry with almost everyone, and therefore become destroyers rather than builders of the nation. Earning a lot of money, developing the Women socially and politically may not necessarily make them honourable and respectable.

Dauda A (2010:20) suggests that "If Women want monetary reward, they should force the government to pay them for undertaking that most important national assignment-child rearing and upbringing-which goes beyond natural role. This is because no matter how much men and Women collectively combine their efforts to develop the nation politically, economically, socially, etc. disgruntled elements, socially maladjusted children, delinquents and hooligans, as well as other social misfits, who have been deprived of parental and especially maternal affection during childhood, will turn against the whole society and destroy everything in order to revenge the injustice done to them." 


\section{Women Empowerment in Relation to their Roles in Society}

Notionally, some of the basic roles of Women in national development include taking up the teaching profession, serving as medical doctors, gynecologists, Dentists and other paramedical staff, as well as social workers, etc. These are however, strictly speaking, developmental roles which are in consonance with the fundamental natural physique, stamina and are psychologically socially and morally healthy for the Womenfolk.

The distribution of labour on the basis of ability, natural disposition and the principle of supplementation rather than competition, ensures societal or national equilibrium. And the moment natural roles are discarded, changed, bastardized or polluted and confused, the societal equilibrium will invariably be disturbed, rendered totally imbalanced and sociopolitical, economic and moral anarchy will be the order of the day. There will be cultural dislocation and moral bankruptcy.

The blunt fact is that any woman who has taken up a job outside her matrimonial home and which is physically exhausting, psychologically destablising and physiologically nerve-breaking is actually over-tasked. Family responsibilities are in themselves sufficiently preoccupying, mentally and physically exhausting, and the whole tasks become psychologically destabilizing, physiologically wrecking and socially overburdening whenever extra burdening assignments are given to the woman outside the home, in the industries, factories, offices or barracks.

\section{Conclusion}

Theoretically, motherhood cannot be studied in any university; it requires the learning of many things, and needs common sense, quick action, love, affection and discipline. A working class mother, (who is a part time housewife) cannot do all that. She has no adequate time for complete motherhood.

Time has come for us to realize that unguided educational training which makes either of the sexes to pursue a line of discipline which is not harmonious with the natural disposition of the student usually results in confusion and unduly making him (the student) to deviate from his naturally accomplishable tasks.

Anne Stevens as cited in Dauda (2010: 20) argued that "some feminists in western Euro American World are of the view that "Women should not be present in the Male-oriented institutions (i. e. fields of human endeavour) of a fundamentally patriarchal social organization... the role of Women is to create and operate new and different structures which are genuinely relevant to Women concerns"

Economic productivity is not the only criterion, not even the most fundamental index for measuring a nation's development. Nations are increasingly becoming materially crazy and materialism is disastrously becoming a new god which many people now worship. There are other non - quantifiable indexes of an individual's development and that of the nation. But materialism has blinded almost all nations, to the extent that the non material variables are virtually forgotten. Development variables such as happiness, peace, security, social harmony and tranquility, are not materially quantifiable, but they are as important, in fact more important, than materialistic economic prosperity. That is even why Women education and work, will continue to face some problems; more especially with the cancerous dwindling global economic fluctuations and the continuous production of unemployed and unmarried graduates. Schooling without a husband, without economic support and without any bright future, will only compound the problems Women face and cause the development of high tension, irritability psychological holocaust, nervousness, prostitution and an endless state of misery.

\section{Recommendations}

- The policy makers need to gear up and entrench the principle of role-orientation in our education system specifically addressing Women's role as breeders of members of the society.

- It is necessary to improve networks for utilizing findings of research and studies on gender-based issues to raise social awareness on the issue of the right jobs for Women in conformity with their natural dispositions.

- Disseminate data and findings of studies providing information on the performances of Women in their jobs to prove their worth through development of practice- oriented mechanisms targeted at ensuring greater access to education for Women.

- Provision of specialized school and vocational counseling, free of stereotypes reinforcing the segmentation of the labor market and de- feminization of some of the patriarchial roles

- The Nigerian government should arrange to pay some stipend to married Women after schooling for 
undertaking the most important national assignment-child rearing and upbringing-which is a sociological and natural role

\section{References}

Aja-Okorie Uzoma Women Education in Nigeria: problems and implications for family role and stability European Scientific Journal October 2013 edition vol.9

Dauda Aliyu, 2010 Women's Education: Its Problems and Prospects Manifold Publishing Company Limited, AKCC Corner Shops Kano Nigeria

J.A. Olawepo \& A.A Jekayinfa. Education as a means of empowering nigerian Women toParticipate actively en politics and Government Nigerian Journal of Social Studies Review 8 (2), 1999

Prospects: a quarterly review of education Women and education: progress and problems VIEWPOINTS/CÓNTROVERSIES U N E S C O VOL. XXI, No. 2, 1991 (78)

U.S. Department of Labor http://www.bls.gov/cps/cpsaat11.htm Retrieved 2862014 